\title{
An Analysis of Factors Influencing the Income Level of Cattle Ranchers on Kabupaten Serdang Bedagai
}

\author{
Arwansyah ${ }^{1, *}$, Eko Wahyu Nugrahadi ${ }^{1}$, Muhammad Yusuf ${ }^{1}$, Joko Suharianto ${ }^{1}$ \\ ${ }^{1}$ Universitas Negeri Medan \\ *Corresponding Author.Email: arwansyah@unimed.ac.id
}

\begin{abstract}
One of sectors present a main contribution improving district net income on Kabupaten Serdang Bedagai is on agricultural with husbandry sub-sector, which sub-sector has a closed chain from upstream to down compared to another sector. The objective of this study is to determine the value influence of price in cattle, beef production, the labor locally and their experiences in breeding and the capital required upon their income rate as breeder found on Kabupaten Serdang Bedagai for the period 2013-2017. This research is a multiple linear regression method with panel data and with cross section. The analysis indicated that variables as used in this research is in fact describe out the variable of local community income rate as breeder living on the area. It is partially showed that the variable of cattle price, their experiences in breeding and capital required influencing positively and significantly with a reliable rate of $90 \%$, still the labor in family influencing positively and significantly with reliable rate of $90 \%$, whereas production of beef influencing not significantly to their family income as breeder during their business in the breeding.
\end{abstract}

Keywords: Breeding, Production of Beef, Labor in Family, Income Rate

\section{INTRODUCTION}

In achieving the predetermined regional development objectives, it is necessary to scale the priorities of development of each region and to make well and sustainable plan. This means that this year's development is a continuation of the development in the past year. Further, the result of this year's development is also set as the basis for determining, planning and creating the development policy in the following year. This planning can be implemented well if the local planners comprehensively understand the problems of the regional development itself-either macro or micro issues as well as the internal and external problems. The development objectives include various economic sectors, which is often measured by Gross Domestic Product (GDP). GDP is the output of various sectors in a regional economy, and is a picture of the macro regional economy.

One of the sectors that provides the greatest contribution is the agricultural sector, which is included in this sector and plays the strategic role in the framework of regional economic development is the role of livestock sub-sector, where this sub-sector has strong links from upstream to downstream in comparison with other sectors. Ministry of Agriculture of Indonesia through the Directorate General of PKH proclaimed the PSDSK
(Self-Sufficiency Program of Beef and Buffalo) program. Previously this program was proclaimed for 2013, but for one reason or another it was revised to 2017.

Some of the strategies pursued by the Directorate General of PKH for achieving the self-sufficiency programs of Beef and buffalo for 2013-2017 are:

a) Streamlining the flow of livestock products by increasing the efficiency of distribution

b) Enhancing competitiveness of livestock products by maximizing the local power.

c) Reinforcing the regulations for local farmers and improving the coordination and cooperation among the related sectors as well as networking among regions.

d) Enhancing farmer promotional products for export.

The achievement of the target of self-sufficiency in meat in 2017 is highly dependent on the success of breeding industry, feedlot industry, slaughterhouses industry and beef-based processing industry. The real challenges currently faced include the availability of feed, livestock cultivation, marketing, distribution and transportation. As part of regional development, the development of livestock in Serdang Bedagai Regency of 
North Sumatra province is integrated into the agricultural sector development program. Revitalizing agriculture is one of the government's development priorities, which is directed as the efforts of strengthening food security, increasing productivity, competitiveness and valueadded agricultural products, as well as increasing knowledge and skills of farmers, including the access to capital. In line with the agricultural development program, livestock development is directed to participate in maintaining food security and increasing productivity.

The Agriculture and Husbandry Office of Serdang Bedagai Regency classifies livestock species into several commodities, namely cattle, dairy cows, buffaloes, sheep and pigs (categorized into large livestock), broiler, laying chicken, poultry, duck and quail (categorized into small livestock). What is analysed in this study is large livestock. This is because the small livestock data is of inadequate availability and the maintenance of large livestock requires special attention and involves various interests, including the government of Serdang Bedagai Regency.

Table 1. Livestock Population in Serdang Bedagai Regency 2017

\begin{tabular}{|c|l|r|r|}
\hline No. & \multicolumn{1}{|c|}{$\begin{array}{c}\text { Type of } \\
\text { Livestock }\end{array}$} & Population & Percentage \\
\hline 1. & Cow & 43,503 & 0.76 \\
\hline 2. & Goat & 74.284 & 1.31 \\
\hline 3. & Sheep & 40,352 & 0.71 \\
\hline 4. & Pig & 29,455 & 0.52 \\
\hline 5. & Chicken & & \\
\hline 6. & Duck & $5,148,203$ & 90.47 \\
\hline 7. & Quail & & 1.56 \\
\hline Number of Livestock & $5,690,314$ & 100.00 \\
\hline
\end{tabular}

Source: Department of Agriculture and Husbandry of Serdang Bedagai Regency

Table 1 demonstrates the large number of livestock population cultivated by local farmers in Serdang Bedagai Regency during 2017 which is as many as $5,690,314$ animals consisting of 7 (seven) livestock species of the largest population.

Chicken has the largest number of population which is as many as 5.148 .203 or about $90.47 \%$ of the entire livestock population during 2017 , duck is as many as 265,717 or about $4.67 \%$ and quail is as many as 88,800 heads or about $1.56 \%$. The smallest livestock population is pig which is as many as 29.455 or approximately $0.52 \%$ of the total population, followed by sheep which is as many as 40.352 or about $0.71 \%$ and cattle as many as 43.503 , or about $0.76 \%$.

One of the biggest contributing factor in increasing the income of cattle farmers in Serdang Bedagai is the livestock ownership. The more cattle the farmers have, the more income they will get and vice versa.

The data released by BPS and the Department of Agriculture and Livestock of Serdang Bedagai Regency shows the statistics of cattle population which is owned by the farmers during the 2013 to 2017 as presented in Figure 1.

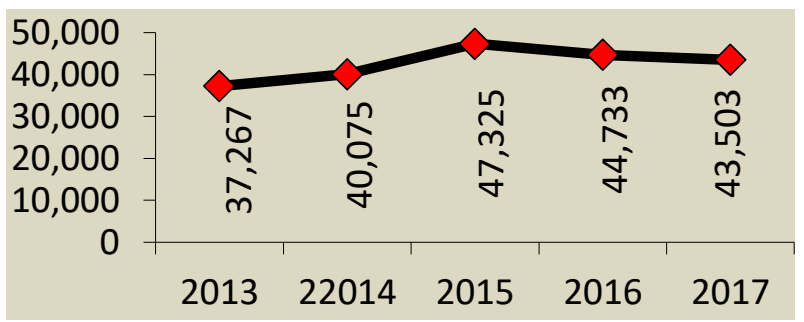

Figure 1. Cattle Population in Serdang Bedagai Regency Year 2013 - 2017

Figure 1 show that in 2013, the number of cattle populations sought was as many as 37.267 , while in 2014 , the ownership of cattle was increased to as many as 40.075 .

In 2015 the number of cattle had a relatively significant increase due to the donation given by Serdang Bedagai Government in the form of cattles for communities aimed at improving the income of farmers. The most obvious impact of this assistance was the skyrocketing cattle population in 2015 to as many as 47.325 .

The other indicators which also influence the level of farmer's income is the generated livestock production such as the livestock meat per se. The increase in meat production will bring profit or surplus for producers (farmers). Sugiarto [42] states that in microeconomic theory, consumer surplus showed a surplus of satisfaction enjoyed by consumers. The advantages of this satisfaction arise from the difference between the satisfaction derived by someone when consuming a number of commodity and the payments to be issued for obtaining that commodity. 


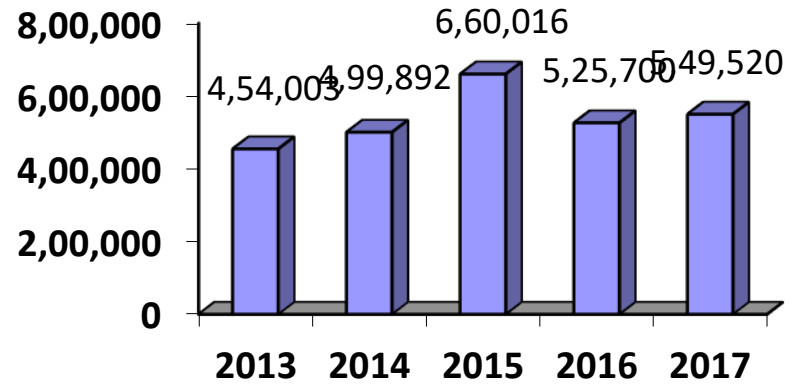

Figure 2. Large Livestock Meat Production in Serdang Bedagai Year 2013 - 2017

Figure 2 showed that from 2013 until 2017 the cattle meat production in Serdang Bedagai increased, as recorded in 2013, the production of large livestock meat was as many as $454.003 \mathrm{~kg}$, while in 2014, meat production was increased to as many as $499.892 \mathrm{~kg}$, compared to 2016 , even in 2015 with a total number of 186.615 of livestock, the meat production was as many as $660.016 \mathrm{~kg}$. However, in 2013 there was a decrease in meat production amounted to $525.700 \mathrm{~kg}$, but then increased in 2017 amounted to $549.520 \mathrm{~kg}$.

Most cattle business in Serdang Bedagai are folk farms which are until now managed traditionally, of small scale, by using simple technology. The main character of farmer households shows that livestock enterprises are managed by households and members of their families down generations. This phenomenon is a household behavior as a producer in economic activities. Households, in addition to their act as producers, are also the providers of labour as well as consumers. Family members labour are allocated to work in the cattle business, farms and others.

\section{RESEARCH PROBLEMS}

Based on the descriptions elaborated previously, the authors formulate the following issues: "How does the livestock price, meat production, family labours, farmers' experience and capital affect the income level of cattle farmers in Serdang Bedagai Regency? "

\subsection{Research Objectives}

This research aims at finding out how much the effect of livestock price, meat production, family labours, farmers' experience and capital to the income level of cattle farmers in Serdang Bedagai Regency.

\section{RESEARCH METHODS}

\subsection{Type and Location of Research}

This research was conducted in qualitative and quantitative descriptive research. The authors describe the observed subject or object in accordance with the data and information and facts obtained in the field during this research. The study was conducted in Serdang Bedagai Regency due to the closer distance which enabled the authors to collect and dig information and data needed in this study more easily.

\subsection{Population and Sample}

In obtaining the intended sample which became the object of this research, several stages were taken. The stages in sampling are intended to make the research be more focused on the scope of the study, as well as to avoid and reduce the error rate.

Population in this research was all cattle farmers who are the members of farmers group in Dolok Masihul District - the districts with the largest livestock population in Serdang Bedagai which is as many as 7.573. them the sample was taken within random sampling by using Slovin formula. There are 88 farmers group in Dolok Masihul District of Serdang Bedagai Regency, from the 22 villages, with a total membership of 1.770 people. The sample size is 94 people which has been randomly selected.

\subsection{Analysis Model}

Descriptive Analysis

Descriptive analysis describes and illustrates the quantitative data obtained from the observation and the answers of the questionnaires given by the respondents in this case the farmers family in Dolok Masihul District, Serdang Bedagai Regency. The general description and characteristics of the respondents is also analysed in addition to the thorough description of their farm animals.

\subsection{Regression Analysis}

Multiple linear regression analysis applies the relationship of more than two variables to get the fit lines, so a variable can be predicted or estimated based on other variables. The estimated variables are called dependant variable which have dependency on some explanatory variables. In regression analysis with cascading time data, if lagged independent variable is included, the model is called auto regressive model. While if the regression model includes the current and lagged explanatory variables, this model is called distributed lag model [6].

This research used the model to explain the effect of livestock price, meat production, family labour, farmers' experience and capital to the income level of cattle farmers in Serdang Bedagai Regency.

\section{RESULTS AND DISCUSSION}

\subsection{Model Estimates}

Estimation of the model in this study is done by using the software Eviews 6.0 with OLS to see the Farmers' Income (Y) wherein, Livestock Prices (X1), Meat Production (X2), Farmers Family Labour (X3), Farmers' Experience (X4) and Farmers' Capital (X5) have an effect on the cattle farmers income $(Y)$ in Serdang Bedagai Regency. 
After getting the results of the model estimation, the economic analysis, statistical analysis and econometric analysis with the model done with the estimation of multiple linear regression equation (OLS) will be done. The discussion of this analysis is based on data that has been formally published and has been stated in the theoretical review and analysis model specification. Then, the economic analysis is conducted to explain the meaning of the parameters obtained from the linear regression equation that has been done, then to see whether these parameters are in conformity with economic theory. Moreover, an analysis is also done to find out the meaning of the coefficient and the effect of changes in the independent variable on the dependent variable.

In this study, the results of the regression estimates for the effectiveness function can be seen in the following table:

Table 2. Estimation of Farmers' Income Model (Y)

Dependent Variable: LOG (Y)

Method: Least Squares

Date: 05/14/16 Time: 20:12

Sample: 194

Included observations: 94

\begin{tabular}{cccrr}
\hline \hline & & & \\
& Coefficient & Std. Error & T-Statistic & Prob. \\
\hline \hline C & & & \\
LOG (X1) & -22.78403 & 3.688207 & -6.177537 & 0.0000 \\
LOG (X2) & 1.977074 & 0.275336 & 7.180593 & 0.0000 \\
LOG (X3) & -0.031129 & 0.045700 & -0.681164 & 0.4976 \\
LOG (X4) & -0.359258 & 0.059119 & -6.076836 & 0.0000 \\
LOG (X5) & 0.650307 & 0.054297 & 11.97687 & 0.0000 \\
& 0.331417 & 0.070627 & 4.692492 & 0.0000 \\
\hline \hline & & & \\
R-squared & & & \\
Adjusted R-squared & 0.979863 & Mean dependent var & & 15.09222 \\
SE of regression & 0.978719 & SD dependent var & & 0.617298 \\
Sum squared resid & 0.090052 & Akaike info criterion & & -1.915162 \\
Log likelihood & 0.713621 & Schwarz criterion & & -1.752824 \\
F-statistic & 96.01259 & Hannan-Quinn criter. & & -1.849589 \\
Prob (F-statistic) & 856.4118 & Durbin-Watson stat & & 0.868572 \\
& 0.000000 & &
\end{tabular}

Regression analysis of farmer incomes (Y) can be written in the linear equation as follows:

$\log (\mathrm{Y})=-22.78403+1.977074 * \log (\mathrm{X} 1)-$ $0.031129 * \log (\mathrm{X} 2)-0.359258 * \log (\mathrm{x} 3)+0.650307$ $* \log (\mathrm{x} 4)+0.331417 * \log (\mathrm{X} 5)$

The estimation results of the farmers' income model (Y), Livestock Price (X 1), Farmers' Experience (X 4) and Farmers' Capital (X5) shows positive and significant effect on $\alpha=10 \%$ of the cattle farmers' income (Y) in Serdang Bedagai Regency. While family labour (X3) shows negative and significant effect on $\alpha=10 \%$ of the cattle farmers' income (Y) in Serdang Bedagai Regency. Statistical analysis is used to see the validation of the models used in this study. The statistical test is applied to the result of regression model. The statistical test includes the testing of the amount of t-statistics $\mathrm{F}$ statistics, and the value of $\mathrm{R} 2$.

\subsection{Statistical t Test (partial test)}

This t test or partial test is done to see the effect of the independent variable to the dependent variable partially. From the estimation result of the model for farmers' income (Y), the value of $t$ for each variable is written as follows

1) Livestock Prices (X1) in the farmer's income (Y) the value of two observed $=7.180593$ with probability level of 0.0000 . This indicates that the probability value is smaller than $\alpha=0.10$, so that the variable $\mathrm{X} 1$ is significant on the reliance level degrees by $90 \%$ positively influences the farmers' income (Y), which means that in case there is an increased 
livestock prices (X1) as to $1 \%$, then the farmer's income (Y) will increase to the coefficient which is equal to $1,98 \%$, ceteris paribus.

2) Meat Production (X2) in the farmer's income (Y) the value of two observed $=-0.681164$ with probability level of 0.4976 . This indicates that the probability value is bigger than $\alpha=0.10$, so that the meat production variable (X2) is not significant on the reliance level degrees by $90 \%$ affecting the farmers' income $(\mathrm{Y})$.

3) Family labour (X3) in the farmer's income (Y) the value of tobserved $=-6.076836$ with probability level of 0.0000 . This indicates that the probability value is smaller than $\alpha=0.10$, so that the variable $\mathrm{X} 3$ is significant on the reliance level degrees by $90 \%$ negatively influences the farmers' income (Y), which means that in case there is an increased number of family labour (X 3) to $1 \%$, then the farmer's income (Y) will decrease to the coefficient which is equal to $0,36 \%$, ceteris paribus.

4) Farmer's Experience (X4) in the farmer's income (Y) the value of tobserved $=11.97687$ with probability level of 0.0000 . This indicates that the probability value is smaller than $\alpha=0.10$, so the farmer's experience (X4) significantly affects the farmer's income (Y) on the reliance level degrees by $90 \%$, which means that in case of farmers experience increased (X4) by $1 \%$, then the farmer's income (Y) will increase to the coefficient which is equal to $0,65 \%$, ceteris paribus.

5) Farmer's Capital (X5) in the farmer's income (Y) the value of two observed $=4.692492$ with probability level of 0.0000 . This indicates that the probability value is smaller than $\alpha=0.10$, so the farmer's capital variable (X 5) is significant on the reliance level degrees by $90 \%$ positively influences the farmers' income (Y), which means that in case of increased farmer's capital (X5) by $1 \%$, then the farmers' income (Y) will increase to the coefficient which is equal to $0,33 \%$, ceteris paribus.

\subsection{Statistical F Test (Simultaneous Test)}

This $\mathrm{F}$ test is done to find out the simultaneous effect of independent variables on the dependent variables. From the estimation result of farmer income model (Y), it is obtained that the value of Fobserved is 856.4118 with probability level of 0.0000 . This suggests that the independent variable for cattle farmers income (Y) are the Livestock Price (X1), Meat Production (X2), Family Labour (X3), Farmer's Experience (X4) and Farmer's Capital (X5) simultaneously and significantly affect the dependent variable which is the farmer's income (Y) on the reliance level degrees by $90 \%$.

\subsection{The Coefficient of Determination (R2) Test}

The coefficient of determination (R 2) Test is used to find out how much is the variety of independent variables at explaining the dependent variable. From the estimation result of farmer's income (Y), it is obtained that the value of $\mathrm{R} 2$ is 0.979863 . This means that at $97,99 \%$ of the farmer's income can be explained by the variables of Livestock Price (X 1), Meat Production (X 2), Family Labour (X3), Farmer's Experience (X 4) and Farmer's Capital (X5). While the remaining 2,01\% is explained by other variables outside the model.

\subsection{Discussion}

The Effect of Livestock Price to Farmer's Income in Serdang Bedagai Regency

The price is one of the indicators for assessing an item in the unit value of rupiah. The price of a good and service depends on the quality and quantity of the goods in addition to the demand for the goods and services themselves. The more demand for goods and services, the higher the price of goods and services and vice versa. Based on the t test, it is obtained that the probability value of t-statistic of 0.0000 is smaller than $\alpha=0.10$ and positive, which means that the livestock price has a positive and significant impact on the farmer's income in Serdang Bedagai. This implies that any increase in the price of $1 \%$, will increase the income of cattle farmers in Serdang Bedagai by $1,98 \%$, and when the price of cattle decreased by $1 \%$, the cattle farmer's income in Serdang Bedagai will also be decreased by $1.98 \%$.

Thus, the results of this study are in accordance with the theories and hypotheses as well as the previous research by Priyanto [30] which shows the number of breeders maintained significantly contributes to increase the business scale. Similarly, the number of family members, the selling price of livestock, the area of land and the total household income is also positive as a determinant of recommendation for the development of the scale of livestock business.

\subsubsection{The Effect of Meat Production to Farmer's Income in Serdang Bedagai Regency}

Based on the t test, it is obtained that the probability value of t-statistic of 0.4976 Is greater than $\alpha=0.10$ and negative, which means that these variables does not have significant effect on cattle farmer's income in Serdang Bedagai.

These results are not in accordance with the probability theories and hypotheses which claiming that meat production has positive and significant impact on the cattle farmer's income. This can be explained because the meat produced includes the imported meat or ones coming from outside of the region. Thus, meat production here is not only from local meat production. The abundance of meat originating from outside the region will threaten the domestic market and will indirectly affect the cattle farmer's income itself.

\subsubsection{The Effect of Family Labours to Farmer's Income in Serdang Bedagai Regency}


From the research results, it can be explained that the family labour has significant effect on cattle farmer's income in Bedagai Serdang, $\mathrm{k}$ due to the probability value of t-statistic is less than $\alpha=0.10$ which is equal to 0.0000 negatively. This means that if the family labor is increased by $1 \%$, it will decrease the income of cattle farmers by $0.36 \%$, ceteris paribus.

The results of this study can explain that the labour added at some maximum utility point will become the production costs. In other words, adding the labour without adding the production capital - for example the livestock itself - would becoe the cost of production expenses.

\subsubsection{The Effect of Farmer's Experience to Farmer's Income in Serdang Bedagai Regency}

The results showed that the probability value of $\mathrm{t}-$ statistic is smaller than $\alpha=0.10$, which indicates that farmer's experience has significant and positive effect on cattle farmer's income in Serdang Bedagai. This means when farmer's experience is increased $1 \%$ by attending various training, the farmer's income will increase amounted to $0.65 \%$, ceteris paribus.

The results also correspond with previous studies by Saleh [34] in his research which indicates that the scale of effort (number of cows), the farming motivation has very significant effect on the income of farmers. While the farmers' age, education level, farming experience, the number of dependents of the family and the number of labour do not significantly affect the income of farmers.

It can also be argued that farmer's experience does not necessarily affect the farmer's income, which means that farmers who have long been involved and strived in the livestock sector in particular to raise cattle but does not follow the development of science-related businesses, will be left behind and will not impact on the progress of his business.

Meanwhile, farmers who do not have experience but can adapt to increase knowledge related to his business, will have a positive impact on the progress of his business - in this case in the livestock sector, especially cattle.

\subsubsection{The Effect of Farmer's Capital to Farmer's Income in Serdang Bedagai Regency}

The results showed the probability value of t-statistic is smaller than $\alpha=0.10$ that is equal to 0.0000 which means that farmer's capital has positive significant effect on the income of cattle farmers in Serdang Bedagai.

This implies that if there is a capital increase of farmers by $1 \%$, the farmer's income will increase as to $0,33 \%$, and the decrease in farmer's capital of $1 \%$ will decrease the farmer's income by $0.33 \%$.

For small tables, please place it within a column and bigger table be placed in a text frame spanning to both columns. Use the Table facility available within the
MSWord. The font in the row header should be bold and you can use the style available from the style palette.

\section{CONCLUSION}

1) From the estimation of the farmer's income, it is found out that the value of R 2 is 0.979863 , which means that the farmer's income can be explained by Livestock Price, Meat Production, Family Labour, Farmer's Experience and Farmer's Capital amounted to $97.99 \%$, while the remaining $2.01 \%$ is explained by other variables outside the model.

2) The variables used to explain the farmer's income in Serdang Bedagai, North Sumatra Province reveals that the variables of Livestock Price, Farmer's Experience and Farmer's Capital are positive and significant with a confidence level of $90 \%$, the variable of family labour is negative and significant with a confidence level of $90 \%$, while the variables of Meat Production has no significant effect on farmer's income Serdang Bedagai, North Sumatra Province

3) Results of the estimation model for farmer income shows that the value of Fobserved is 856.4118 with a probability level of 0.00000 , which indicates that the variables of Livestock Price, Meat Production, Family Labour, Farmer's Experience and Farmer's Capital simultaneously and significantly affect the dependent variable which is the farmer's income on the confidence level of $90 \%$.

\section{REFERENCES}

[1] Ari Sudarman., "Theory of Micro Economics", fourth edition. Yogyakarta: BPFE Yogyakarta, 2004.

[2] Agung, I.G.N., Pasay, N.H.A., Sugiharso, "Theory of Micro Economics, An Applied Production Analysis", Publisher PT Raja Grafindo Persada, Jakarta, 2008.

[3] Antryandarti. E, "Micro Economy for Agricultural Science", Publisher Nuha Litera, Yogyakarta, 2012.

[4] Central Statistics Agency, "Data Collection of Beef Cattle, Dairy Cattle, and Buffalo 2011 [PSPK2011] Serdang Bedagai Regency" North Sumatra Province, 2011.

[5] Central Bureau of Statistics, "Serdang Bedagai In Figures 2013", Sei Rampah, 2013.

[6] Djalal Nachrowi and Usman Hardius, "The Use of Econometric Techniques", Issue I, First Matter, Raja Grafindo Persada, Jakarta, 2002.

[7] Daroini, Analysis of "Factors Affecting Individual Beef Cattle Livestock Revenues in Kediri", Thesis, 2013.

[8] Serdang Bedagai District Agricultural Service, "Strategic Plan of Serdang Bedagai District Agricultural Service 2009-2014" (unpublished) 
[9] Director General of Animal Husbandry and Animal Health, \ "Guidelines on Implementation of Livestock and Keslaw State Budget Management", Jakarta, 2012.

[10] Djajanegara, A., and Diwyanto, K., "Development strategies for genetic evaluation of beef production in Indonesia". Proc. of an International Workshop, Held in Khon Kaen Province, Thailand, July 23-28, 2001. ACIAR. No. 108. Erlina, 2011, "Research Methodology", Publisher USU Press, Medan., 2001.

[11] Gujarati, D.N., "Basic Econometrics", McGrawHill, Inc. New York, 2004.

[12] Indah, Susantun, "The Benefits of Cobb-Doughlas In Estimating Relative Economic Efficiency", Journal of Development Economics, Rajawali Pers, Jakarta, 2000.

[13] Jinghan, M. L., "Economic Development and Planning", Rajawali Pers, Jakarta, 2000.

[14] Lau, Lawrence J, and Pan A, Yotopoulus, "Profit, Supply and Demand Function, American Journal of Agriculture Economics", 1972.

[15] Lubis. W.O., "Impact of Cattle Commodity Development on Increasing Revenue and Regional Development in Hamparan Perak Subdistrict of Deli Serdang Regency", Thesis, Post Graduate Program of University of North Sumatra, Medan, 2010.

[16] Kalangi, J.K.J, "Analysis of Beef Cattle Business in Kecamatan Kawangkoan". Zootek Journal, 2008.

[17] Mankiw, N.G, D.Romer, and D. Weil, "A Contribution to The Empirics of the Economic Growth", Quarterly Journal of Economics, 2003.

[18] Matatula. M.J, "Financial Analysis of Beef Cattle Livestock Farming in Kairatu District, West Seram District", Agroforestion Volume V Number 3, 2010.

[19] Mersyah. R, "Sustainable Crop Husbandry System Design to Support the Implementation of Regional Autonomy in South Bengkulu Regency", Desertation, Post-Graduate Program, IPB-Bogor, 2004.

[20] Miller, Roger Le Roy, Meiners, Roger E, "Theory of Economic Intennediate", Hans Munandar's Translation. Pt Raja Grafindo Persada. Jakarta, 2000.

[21] Mubyarto, "Introduction to Agricultural Economics", LP3ES, Jakarta, 1991.

[22] Mudrajat.K, "Research Methods for Business and Economy", Publisher Erlangga, Jakarta, 2003

[23] Nababan, Chritofel, "Analysis of Factors Affecting the Income of Maize Farmers in Tiga Binanga SubDistrict of Karo Regency". Thesis: Faculty of
Economics, Islamic University of North Sumatra, 2009.

[24] Nicholson, Walter, "The Economics of Intennediate and Its Applications", Eighth Edition, IGN Bayu Mahendra and Abdul Aziz Translation. Erland. Jakarta, 2002.

[25] Pahlawati. S., "Improving People's Welfare by Beef Cattle Development with Environmental Partnership Pattern", 2012.

[26] Parwati, "Income Analysis and Factors Affecting Production of Goat Livestock with Laserpunktur", Thesis, 2003.

[27] Purbayu, BS, "Business Scale On Dumbo Catfish Cultivation in Kudus Regency, Central Java", Research Magazine Research Institute of Diponegoro University, Year VIII, N0. 28, 1995.

[28] Purnomo, S, "Policy Simulation Model of Income Development of Household Economics of Beef Cattle (Case Study in Kecamatan Damsol of Donggala District)", Dissertation. Universitas Brawijaya Post Graduate Program Malang., 2010.

[29] Putranto. E.H, "Analysis of Profit of Smallholder Livestock Farm in Central Java (Boyolali Regency, Semaran Regency, Semarang City)", Thesis, Postgraduate Program of Diponegoro University, Semarang, 2006.

[30] Priyanto, "Target of Business Scale Values of Livestock Breeding Pattern Supports Farmers Revenue in Rural Areas", Journal of Economics, 2008.

[31] Ramadhani. S., "Analysis of Efficiency, Scale and Production Elasticity With Cobb-Douglas Approach and Multiple Regression", Journal of Technology Volume 4 No. 1, 2011.

[32] Rochaeni, S and E.M. Lokollo,, "Factors Affecting Household Economic Decisions in Kelurahan Situgede Bogor City", Journal of Agro Economics Vol 23, 2006

[33] Romer, D, "Advanced Macroeconomics", Second Edition, New York: McGraw-Hill Book Co., 2002.

[34] Saleh, et al., "Analysis of Income of Beef Breeders in Hamparan Perak Subdistrict of Deli Serdang Regency", Thesis, 2006.

[35] Salvatore, Dominick, "Managerial Ecanomics: Managerial Economy in the Global Economy", fifth edition, Salemba Four, Jakarta, 2005.

[36] Salvatore, Dominick., "Microeconomic Theory", second edition. Jakarta, Erland, 1995.

[37] Samuelson, P.A. and Nordhaus, W.D, "Micro Sciences Economics", Interpretation by Nur Rosyidah, Anna Ellyy and Bosco Carvalo, Publisher of PT. Media Global Edukasi, Jakarta, 2003. 
[38] Soekartawi, "Analysis of Farm Enterprises". UI Press, Jakarta, 2002.

[39] Soekartawi, "Theory of Production Economics with the Principles of Analysis of Cobb Douglas Functions", CV Rajawali. Jakarta, 2003.

[40] Sudarsono, "Introduction to Micro Economics". Jakarta: LP3ES, 1995.

[41] Sudirman, B, "Efficient Use of Production Factor in Farming in Sidenreng Rappang District: econometric approach", Thesis, 1989.

[42] Sugiarto, at al, "Microeconomics A Comprehensive Study", Publisher Gramedia Pustaka Utama. Jakarta, 2005.

[43] Suharno, B and Nazaruddin, "Commercial Livestock", Penebar Swadaya, Jakarta, 2006.

[44] Sukanata, I.W, Suciani, I. G. N, Kayana, IW, Budhiarta, "The Impact of Implementation of Interisland Cattle Trade Quota on Welfare of Breeders and Cattle Population in Bali Province", The Excellence Research Universitas Udayana, Bali, 2011.

[45] Sukirno, Sadono, "Micro Economy: Theory of Introduction", Third Edition, Jakarta, PT. Raja Grafindo Persada , 2009.

[46] Suryana, "Agribusiness-Oriented Livestock Breeding Business Development with Partnership Pattern", R \& D, Jakarta, 2009.

[47] Suryati, "Theory of Micro Economy", UPP, AMIP, YPKN, Jogiakarta, 2004.

[48] Swastika, DKS. Agustian, Adang. Sudaryanto, Tahlim, "Analysis of Food Supply Corn Demand and Demand with Synchronization Approach to Production Centers, Feed Mill, and Livestock Population in Indonesia" Ministry of Agriculture, 2011.

[49] Tarigan. R., "Regional Economy", Publisher PT. Bumi Aksara, Jakarta, 2006.

[50] Tarigan, R., "Regional Planning", Publisher PT. Bumi Aksaran, Jakarta, 2009.

[51]T, Gilarso, "Introduction to Microeconomics", revised edition, Kanisius, Yogyakarta, 2003.

[52] Yasin. S, "Ruminant Livestock Production", Publisher Pustaka Reka Cipta, Bandung, 2013.

[53] Yulianto. P and Saparinto. C, "Fattening Beef Cattle Day Per Day 3 Month Harvest", Publisher Penebar Sradaya, Jakarta, 2012.

[54] Yusdja Y, "Economic Policy of Dairy Agribusiness Industry in Indonesia", Bogor, Indonesian Center for Agriculture Socio Economic and Policy Studies, 2005 .
[55] Yotopoulus, Pan A and Nugent JB, "Economic Development, Empirical, Investigation, Harper and Row Publisher", New York, 1976.

[56] Waridin, "Business Scale and Efficiency of Farmer Economic Economy on Land Status of Lease", Research Magazine of Research Institute of Diponegoro University, Semarang, 1995. 